\title{
KARAKTERISTIK PERTUMBUHAN MISELIUM JAMUR TIRAM PUTIH (Pleurotus ostreatus) PADA MEDIUM DASAR JERAMI DAN TONGKOL JAGUNG
}

\section{Growth Characteristics Of The Mycelium Of The White Oyster Mushroom (Pleurotus ostreatus) on straw basis medium and corn cob}

\author{
Umrah", I Nengah Suwastika, Eny Yuniati, Rifka, Nurvita \\ Jurusan Biologi Fakultas Matematika dan IImu Pengetahuan Alam Universitas Tadulako
}

Keywords:

Mycelium, Corn Straw, Corn Cob, Number of colonies.

Kata Kunci:

Miselium, Jerami Jagung,

Tongkol Jagung, Jumlah koloni.

\begin{abstract}
The growth rate of mycelium of white oyster mushroom (Pleurotus ostreatus (Jacq) $\mathrm{P}$. Kumm) using straw and corn cobs as the base medium was carried out at the Microbiology Laboratory, Department of Biology, Faculty of Mathematics and Natural Sciences. Research purposes; (a) To observe the growth of white oyster mushroom (Pleurotus ostreatus) in the formulation of straw and corncob waste media; (b) To determine the ratio of the dose of straw waste and corn cobs that can provide the best growth of white oyster mushrooms. This study was designed based on a completely randomized design (CRD) consisting of 7 treatments and 3 replications. The treatment arrangement is a comparison between corn straw powder: corn cob powder, namely $\mathrm{P} 1$ (100\% straw powder, without corncob powder), P2 $(80 \%+20 \%)$, P3 $(60 \%+40 \%)$, P4 $(40 \%+60 \%)$, P5 $(20 \%+80 \%)$, P6 $(100 \%$ Corncob Powder, without Straw Powder), P7 $(70 \%$ Sawdust $+20 \%$ Rice Bran $+10 \%$ Corn Flour, without Straw Powder and Corncobs). Observation parameters; (a) Basic growth medium; (b) Microscopic characteristics of hyphae; (c) Mycelium growth rate; (d) Macroscopic characteristics of the colony; (e) Incubation period. The results showed the fastest mycelium growth rate in treatment P4 was $103 \mathrm{~mm}$ and the lowest in treatment P1 was $75 \mathrm{~mm}$. The highest number of colonies (CFU) in treatment P7 was $1.6 \times 1012 \mathrm{CFU} / \mathrm{g}$ and the lowest in treatment P4 was $0.2 \times 1012$ CFU $/ \mathrm{g}$. The fastest incubation time in P7 treatment was 28 days and the lowest in P4 treatment was 30 days.
\end{abstract}

\begin{abstract}
ABSTRAK
Laju pertumbuhan miselium jamur tiram putih (Pleurotus ostreatus (Jacq) P. Kumm) dengan medium dasar jerami dan tongkol jagung telah dilaksanakan di Laboratorium Mikrobiologi Jurusan Biologi Fakultas Matematika dan IImu Pengetahuan Alam. Tujuan Penelitian; (a) Untuk mengamati pertumbuhan jamur tiram putih (Pleurotus ostreatus) pada formulasi media limbah jerami dan tongkol jagung; (b) Untuk mengetahui perbandingan dosis limbah jerami dan tongkol jagung yang dapat memberikan pertumbuhan terbaik terhadap jamur tiram putih. Penelitian ini didesain berdasarkan Rancangan Acak Lengkap (RAL) yang terdiri dari 7 perlakuan dan 3 kali ulangan. Susunan perlakuan merupakan perbandingan antara Serbuk jerami jagung : serbuk Tongkol Jagung yakni P1 (Serbuk Jerami 100\%, tanpa Serbuk Tongkol Jagung), P2 $(80 \%+20 \%)$, P3 $(60 \%+40 \%)$, P4 $(40 \%+60 \%)$, P5 $(20 \%+80 \%)$, P6 (Serbuk Tongkol Jagung 100\%, tanpa Serbuk jerami), P7 (Serbuk Gergaji 70\% + Dedak Padi 20\% + Tepung Jagung 10\%, tanpa Serbuk Jerami dan Tongkol Jagung). Parameter pengamatan; (a) Media dasar pertumbuhan; (b) Karakteristik mikroskopik hifa; (c) Laju pertumbuhan miselium; (d) Karakteristik makroskopik koloni; (e) Masa inkubasi. Hasil penelitian menunjukkan laju pertumbuhan miselium tercepat pada perlakuan P4 yaitu $103 \mathrm{~mm}$ dan terendah pada perlakuan P1 yaitu $75 \mathrm{~mm}$. Jumlah koloni (CFU) tertinggi pada perlakuan P7 yaitu $1,6 \times 10^{12} \mathrm{CFU} / \mathrm{g}$ dan terendah pada perlakuan $\mathrm{P} 4$ yaitu $0,2 \times 10^{12} \mathrm{CFU} / \mathrm{g}$. Waktu inkubasi paling cepat pada perlakuan P7 yaitu 28 hari dan terendah pada perlakuan $\mathrm{P} 4$ yaitu 30 hari.
\end{abstract}




\section{PENDAHULUAN}

Jamur tiram merupakan jamur kayu yang dapat dikonsumsi oleh masyarakat yang memiliki kandungan gizi yang cukup tinggi seperti vitamin, protein, karbohidrat dan niasin (Suryani dan Carolina, 2017). Jamur tiram enak dimakan dan dipercaya mempunyai khasiat sebagai obat dan membantu penurunan berat badan karena berserat tinggi dan membantu pencernaan (Sunarmi dan Saparinto, 2010).

Jamur dengan genus Pleurotus yang tergolong ke dalam kelas Basidiomycetes adalah salah satu jenis jamur yang dapat dimakan (Mondal et al., 2010). Jamur tiram putih (Pleurotus ostreatus) merupakan jenis jamur tiram yang memerlukan nutrisi selulosa dan lignin untuk pertumbuhannya (Iswahyudi dkk., 2017).

Jamur tiram putih dapat ditemukan di daerah sub tropis, yang digemari oleh masyarakat karena cita rasanya yang khas. Jamur tiram putih dapat diolah menjadi beragam menu makanan sesuai dengan selera bagi penikmat jamur itu sendiri. Selain memiliki rasa yang khas jamur tiram putih juga mengandung senyawa kimia yang dapat mencegah penyakit dan baik bagi kesehatan tubuh. Pada jamur tiram ditemukan senyawa kimia seperti protein, fosfor, lemak dan ribovlavin (Suparti dan Marfuah, 2015).

Jamur tiram dapat tumbuh pada limbah jerami dan tongkol jagung karena adanya kandungan selulosa. Limbah jerami jagung dan tongkol jagung dapat digunakan sebagai substrat pertumbuhan jamur tiram putih, kandungan tepung batang jagung dan tongkol jagung terdiri dari lignin, selulosa, dan hemiselulosa. Batang jagung juga mengandung serat kasar yang tinggi, nilai gizi yang rendah, sehingga dimanfaatkan melalui proses fermentasi untuk menumbuhkan mikroba. Ketersediaan kedua limbah tersebut sangat melimpah sehingga mudah didapatkan. Kandungan nutrisi jerami jagung diantaranya kadar lignin $13,01 \%$, serat kasar $27,61 \%$ dan protein kasar 6,37\% (Mayasari dkk., 2015). Kandungan nutrisi dari tongkol jagung diantaranya yaitu meliputi bahan kering $90,0 \%$, protein kasar $2,8 \%$, lemak kasar $0,7 \%$, abu $1,5 \%$, serat kasar $32,7 \%$, selulosa $25,0 \%$, lignin $6,0 \%$ dan ADF $32,0 \%$ (Murni dkk., 2008).

Berdasarkan uraian di atas maka penelitian ini bertujuan untuk melihat laju pertumbuhan miselium dalam limbah jerami dan tongkol jagung yang dibutuhkan untuk pertumbuhan jamur tiram putih (Pleurotus ostreatus). Selain itu mendorong masyarakat untuk memanfaatkan limbah jerami dan tongkol jagung menjadi media tumbuh serta menjadi solusi untuk penanggulangan limbah yang menumpuk di lingkungan sekitar. 


\section{BAHAN DAN METODE}

Bahan yang digunakan adalah bibit jamur tiram putih (Pleurotus ostreatus), limbah jerami, tongkol jagung, air kelapa, karet gelang, spritus, plastik tahan panas, aquades, kertas label, korek api, selotip, antiseptik, tissue, alkohol $70 \%$, dan media PSA.

Alat yang digunakan adalah parang, pisau, gunting, autoclave, timbangan duduk, jangka sorong, bunsen, spatula, botol kultur, terpal, karung, ember, baskom, cawan petri, hotplate, tabung reaksi, erlenmeyer, gelas ukur, gelas backer, mikroskop binokuler, mikroskop stereo, kaca preparat dan kaca penutup, rak tabung, skop kecil, timbangan analitik, jarum ose, Laminar Air Flow (LAF), mikro pipet, mesin penggiling tepung dan alat tulis.

\section{Rancangan Penelitian}

Penelitian ini didesain berdasarkan Rancangan Acak Lengkap (RAL) yang terdiri dari 7 perlakuan dan 3 kali ulangan. Susunan perlakuan sebagai berikut: P1 (serbuk jerami jagung 100\%), P2 (serbuk jerami jagung $80 \%$ + serbuk tongkol jagung 20\%), P3 (serbuk jerami jagung 60\% +serbuk tongkol jagung 40\%), P4 (serbuk jerami jagung $40 \%+$ serbuk tongkol jagung $60 \%$ ), P5 (serbukjerami jagung $20 \%+$ serbuk tongkol jagung 80\%), P6 (serbuk tongkol jagung 100\%), P7 kontrol positif (serbuk gergaji $70 \%$ dedak padi $20 \%+$ tepung jagung 10\%).

\section{Penyiapan Media}

Limbah jerami dan tongkol jagung diiris tipis berukuran $1 \mathrm{~mm}$ kemudian dikeringkan dengan cara dijemur selama dua atau tiga hari di bawah matahari. Setelah kering, bahan digiling secara terpisah.

\section{Formulasi Media Perlakuan}

P1 terdiri dari $100 \mathrm{~g}$ serbuk jerami jagung dan $100 \mathrm{ml}$ air kelapa. P2 terdiri dari $80 \mathrm{~g}$ serbuk jerami jagung, $20 \mathrm{~g}$ serbuk tongkol jagung dan $100 \mathrm{ml}$ air kelapa. P3 terdiri dari $60 \mathrm{~g}$ serbuk jerami jagung, $40 \mathrm{~g}$ serbuk tongkol jagung dan $100 \mathrm{ml}$ air kelapa. P4 terdiri dari $40 \mathrm{~g}$ serbuk jerami jagung, $60 \mathrm{~g}$ serbuk tongkol jagung, $100 \mathrm{ml}$ air kelapa. P5 terdiri dari $20 \mathrm{~g}$ serbuk jerami jagung, 80 g serbuk tongkol jagung, dan $100 \mathrm{ml}$ air kelapa. P6 terdiri dari $100 \mathrm{~g}$ serbuk tongkol jagung dan $100 \mathrm{ml}$ air kelapa. P7 terdiri dari $70 \mathrm{~g}$ serbuk gergaji ditimbang, $20 \mathrm{~g}$ dedak padi, $10 \mathrm{~g}$ tepung jagung dan $100 \mathrm{ml}$ air kelapa.

\section{Inokulasi dan Inkubasi}

Botol kultur yang telah berisi media diinokulasikan dengan bibit jamur tiram putih secara aseptik. Setelah itu diinkubasi sampai miselium memenuhi botol kultur.

\section{Parameter Pengamatan}

\section{a. Karakteristik mikroskopik hifa}

Pengamatan mikroskopik hifa dilakukan setelah miselium tumbuh dan memenuhi seluruh permukaan botol kultur menggunakan mikroskop cahaya binokuler. 
b. Pertumbuhan miselium pada botol kultur

Pengamatan pertumbuhan miselium pada botol kultur yang kemudian dikategorikan ke dalam kriteria: sangat kurang (1), kurang banyak (2), banyak (3), sangat banyak (4).

\section{c. Laju pertumbuhan miselium}

Pengukuran dilakukan setiap tiga hari, yaitu pada hari ke-3, 6, 9, 12, 15, 18, 21, 24, 27, 30 dengan menggunakan jangka sorong.

\section{d. Jumlah Koloni}

Jumlah koloni dihitung menggunakan rumus :

$\mathrm{CFU}=$ Jumlah koloni $\mathrm{x} \frac{1}{\text { faktor pengenceran }}$

\section{e. Waktu inkubasi}

Waktu tumbuh miselium jamur sampai memenuhi seluruh permukaan media dalam botol kultur.

\section{Analisis Data}

Data kuantitatif dianalisis dengan menggunakan one way anova dan uji lanjut dengan Duncan.

\section{HASIL}

\section{Karakteristik mikroskopik hifa}

Hasil pengamatan mikroskopik miselium jamur tiram puith dapat dilihat pada Gambar 1. Pengamatan mikroskopik dilakukan dengan menggunakan perbesaran $40 \times 10$.

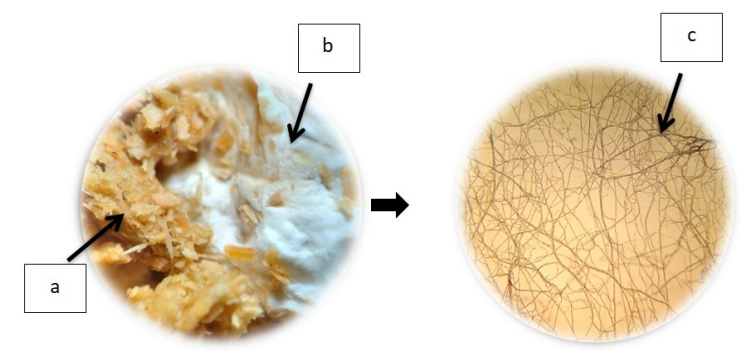

Gambar 1. (a) media dasar, (b) miselium media dasar, dan (c) hifa.

\section{Pertumbuhan miselium pada botol kultur}

Berdasarkan kriteria pertumbuhan miselium pada botol kultur, diketahui bahwa P1, P2, P6, dan P7 berada pada kriteria banyak, sementara P3, P4, dan P5 berada pada kriteria sangat banyak. Kriteria pertumbuhan miselium jamur tiram pada Botol kultur dapat dilihat pada Gambar 2.

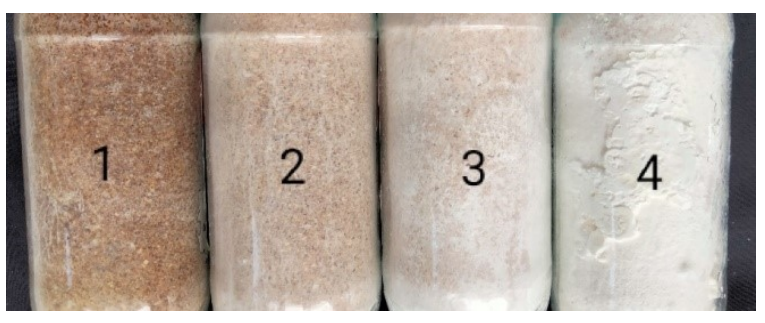

Gambar 2. (1) sangat kurang, (2) kurang banyak, (3) banyak, (4) sangat banyak.

\section{Laju pertumbuhan miselium}

Laju pertumbuhan miselium jamur tiram putih dapat dilihat pada Gambar 3. Petumbuhan miselium dimulai dari hari ke-3 sampai hari ke-30 masa inkubasi. 


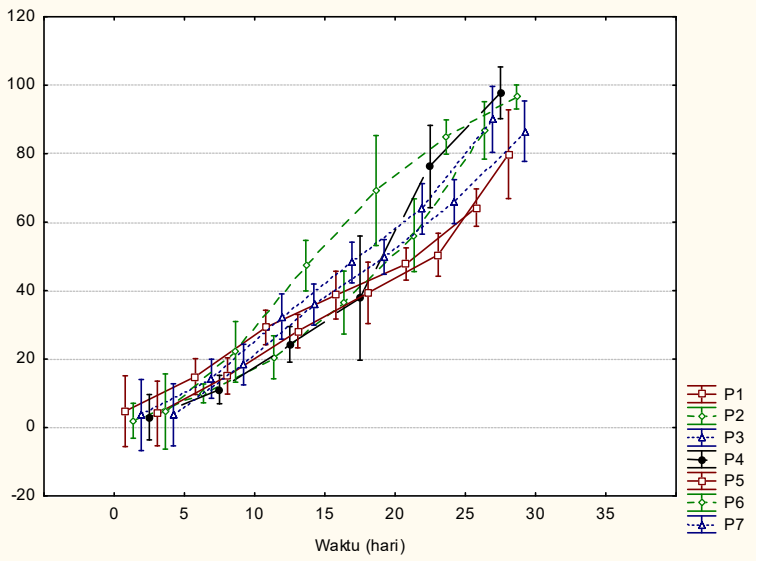

Gambar 3. Laju pertumbuhan miselium jamur tiram putih.

Laju pertumbuhan miselium jamur tiram putih pada botol kultur memiliki kecepatan yang berbeda pada setiap perlakuan. Pengamatan dilakukan selama selang waktu 3 hari (Gambar 3).

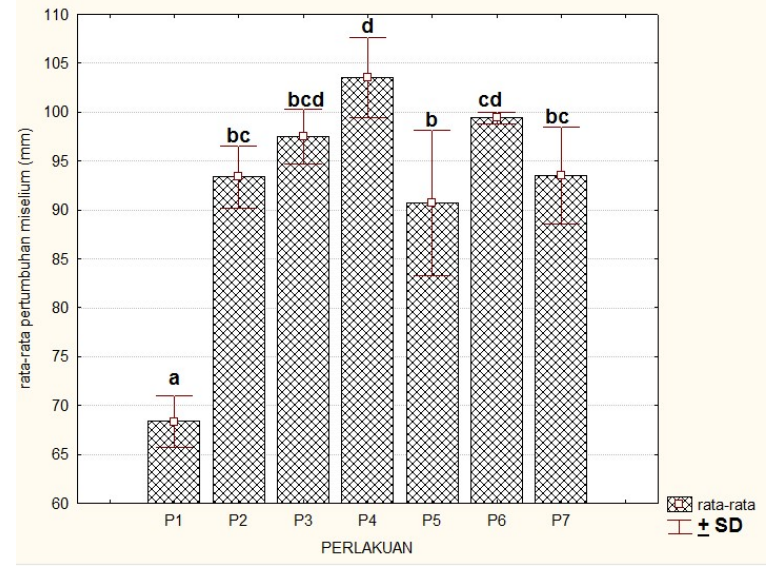

Gambar 4. Rata-rata pertumbuhan miselium pada setiap perlakuan umur 30 hari setelah inokulasi. Huruf yang berbeda terdapat pada bar menunjukkan perbedaan yang nyata pada uji Duncan $5 \%$.

Berdasarkan Gambar 4, pertumbuhan miselium jamur tiram putih paling cepat yaitu pada media P4 (serbuk jerami 40\% + serbuk tongkol jagung 60\%) yang mencapai $\pm 103 \mathrm{~mm}$. Sedangkan pertumbuhan miselium jamur tiram putih paling lambat yaitu pada media P1 (serbuk jerami 100\%) yang mencapai $\pm 63 \mathrm{~mm}$. Hasil uji Duncan pada taraf $5 \%$ diketahui bahwa pertumbuhan miselium pada media $\mathrm{P} 4$ berbeda yang nyata dengan pertumbuhan miselium pada media P1. Hal ini menunjukkan bahwa penambahan serbuk tongkol jagung dapat mendorong pertumbuhan miselium jamur tiram putih.

\section{Jumlah Koloni}

Perhitungan jumlah koloni menggunakan satuan CFU (Colony Forming Unit) hingga pengenceran $10^{-10}$. Perhitungan koloni dilakukan pada hari ke-30 setelah inkubasi. Berdasarkan Gambar 5, setiap perlakuan menghasilkan jumlah koloni yang berbedabeda.

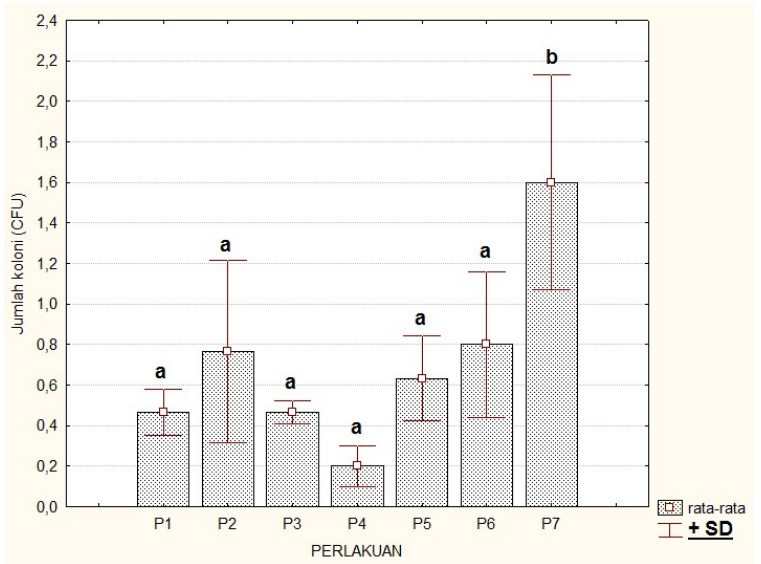

Gambar 5. Jumlah koloni (CFU) pada miselium jamur tiram putih umur 30 hari. Huruf yang berbeda terdapat pada bar menunjukkan perbedaan yang nyata pada uji Duncan $5 \%$. 
Jumlah koloni terbanyak yaitu pada media P7 (serbuk gergaji $70 \%$ + dedak padi $20 \%+$ tepung jagung 10\%) yaitu yaitu $1,6 \times 10^{12} \mathrm{CFU} / \mathrm{g}$. Sedangkan Jumlah koloni paling sedikit yaitu pada media P4 (serbuk jerami $40 \%+$ serbuk tongkol jagung $60 \%$ ) yaitu yaitu $0,2 \times 10^{12} \mathrm{CFU} / \mathrm{g}$. Hasil uji Duncan pada taraf $5 \%$ menunjukkan bahwa Jumlah koloni pada media P1, P2, P3, P4, P5 dan P6 tidak berbeda nyata satu sama lain, namun berbeda nyata dengan jumlah koloni pada media P7.

\section{Waktu inkubasi}

Waktu inkubasi yang dibutuhkan sampai miselium jamur memenuhi media dalam botol kultur berbeda dari ketujuh perlakuan. Masa inkubasi yang dibutuhkan paling lama mencapai hari ke-30 pada media P3 (serbuk jerami jagung 60\% +serbuk tongkol jagung 40\%), P4 (serbuk jerami jagung 40\% + serbuk tongkol jagung 60\%) dan P5 (serbukjerami jagung 20\% + serbuk tongkol jagung $80 \%$ ).

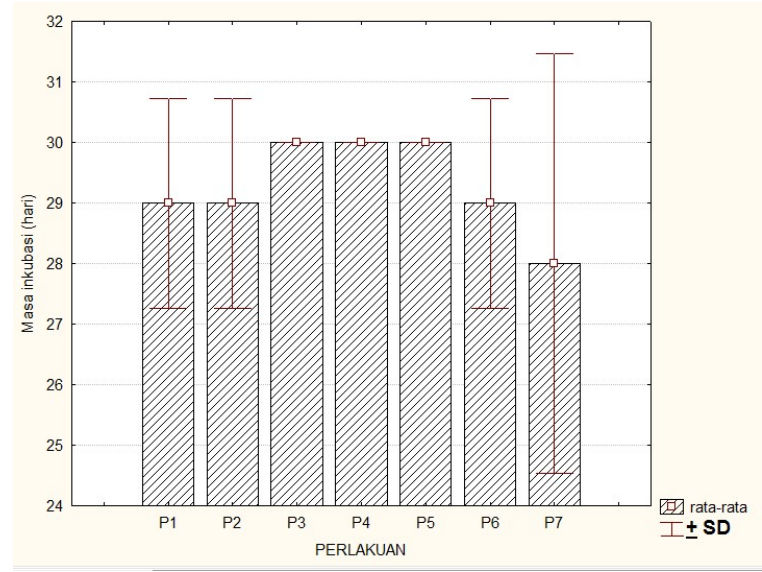

Gambar 6. Rata-rata waktu inkubasi hingga miselium memenuhi media dalam botol kultur.
Berdasarkan Gambar 6, waktu inkubasi paling cepat hingga miselium memenuhi media dalam botol kultur yaitu 28 hari pada media P7 (serbuk gergaji 70\% dedak padi $20 \%$ + tepung jagung 10\%). Pertumbuhan miselium pada media P1 (serbuk jerami jagung 100\%), P2 (serbuk jerami jagung $80 \%+$ serbuk tongkol jagung 20\%) dan P6 (serbuk tongkol jagung 100\%) membutuhkan waktu 29 hari hingga memenuhi media dalam botol kultur.

\section{PEMBAHASAN}

Hasil pengamatan mikroskopik miselium jamur tiram putih yang berasal dari media P4 (Serbuk jerami jagung 40\% + serbuk tongkol jagung 60\%), bagian C pada Gambar 1 menunjukkan karakter hifa yang tidak bersepta. Menurut (Achmad dkk., 2011) ciri-ciri miselium jamur tiram putih yaitu terlihat berwarna putih dan tidak terdapat bintil hitam pada hifa.

Salah satu faktor yang harus diperhatikan dalam pertumbuhan jamur tiram putih adalah media (Masyitah dan Umrah, 2020). Pemilihan media yang akan digunakan sebagai media tumbuh jamur tiram yaitu memiliki selulosa dan serat lignin. Jerami dan tongkol jagung adalah media yang baik bagi pertumbuhan miselium jamur tiram putih karena mengandung selulosa dan serat lignin (Mayasari dkk., 2015; Murni dkk., 2008) yang diperlukan bagi pertumbuhan miselium jamur tiram putih. 
Jerami dan tongkol jagung dipotong menjadi bagian yang kecil setelah itu dikeringkan kemudian digiling dan menjadi tepung yang digunakan sebagai media dasar pertumbuhan jamur tiram. Tingginya kandungan lignoselulosa pada tongkol jagung ini menyebabkan adanya potensi tongkol jagung bertindak sebagai media alternatif dalam budidaya jamur tiram (Hakiki dkk., 2013). Tersedianya nutrisi pada media pertumbuhan menyebabkan miselium jamur tiram putih dapat tumbuh pada setiap media yang digunakan.

Gambar 4 menunjukkan laju pertumbuhan miselium setiap selang waktu 3 hari dan diukur menggunakan jangka sorong (mm) sampai miselium memenuhi seluruh permukaan botol kultur. Menurut (Suharnowo dkk., 2012) pengukuran pertumbuhan miselium pada botol kultur diukur mulai dari bagian atas sampai bagian bawah permukaan botol kultur. Tanda tumbuhnya miselium jamur tiram dengan adanya kumpulan berwarna putih seragam dan sedikit lebih lebat (Suparti dan Karimawati, 2017).

Pertumbuhan miselium tercepat dengan rata-rata laju pertumbuhan mencapai \pm 103 $\mathrm{mm}$ yaitu pada media kombinasi jerami jagung $40 \%+$ tongkol jagung $60 \%$ (P4), sementara pertumbuhan miselium paling lambat dengan rata-rata laju pertumbuhan \pm $63 \mathrm{~mm}$ yaitu pada media jerami jagung $100 \%$ (P1). Analisis varians menunjukkan bahwa media berpengaruh nyata terhadap laju pertumbuhan miselium jamur tiram putih. Pengaruh media terhadap laju pertumbuhan miselium dapat diketahui berdasarkan hasil uji lanjut (Duncan) pada Gambar 1. Berdasarkan hasil uji lanjut, diketahui pertumbuhan miselium pada media kombinasi jerami jagung 40\% + tongkol jagung $60 \%$ (P4) berbeda nyata dengan pertumbuhan miselium media media jerami $100 \%$ (P1). Hal ini menunjukkan bahwa perlakuan dengan komposisi serbuk tongkol jagung yang lebih banyak menyebabkan laju pertumbuhan miselium lebih cepat dibandingkan dengan perlakuan yang lainnya. Hasil penelitian yang sama juga dilaporkan oleh Sutarja (2010), jamur tiram putih dapat tumbuh sangat baik pada media campuran tongkol jagung.

Berdasarkan Gambar 6 waktu inkubasi pertumbuhan miselium jamur tiram putih sampai memenuhi botol kultur berbedabeda. Perlakuan yang terhitung paling cepat pertumbuhannya yaitu perlakuan P7 (serbuk gergaji $70 \%+$ dedak padi $20 \%+$ tepung jagung $10 \%$ ) sebagai kontrol positif dengan rata-rata waktu inkubasi selama 28 hari sedangkan perlakuan paling lambat pertumbuhannya yaitu perlakuan P4 (serbuk jerami jagung $40 \%+$ serbuk tongkol jagung 60\%) rata-rata waktu inkubasi selama 30 hari. Menurut (Wardiah dkk., 2014) bahwa perbedaan konsentrasi pada 
perlakuan dapat memberikan pengaruh yang berbeda terhadap kecepatan pertumbuhan miselium karena diasumsikan terdapat perbedaan nutrisi yang terkandung di dalamnya.

Miselium jamur tiram putih dapat tumbuh pada setiap media perlakuan yang digunakan. Berdasarkan hasil uji Duncan pada taraf $5 \%$ menunjukkan bahwa Jumlah koloni pada media P1, P2, P3, P4, P5 dan P6 tidak berbeda nyata satu sama lain. Namun dari perlakuan tersebut, media P4 (jerami jagung $40 \%+$ tongkol jagung $60 \%$ ) adalah formulasi media paling baik dengan laju pertumbuhan miselia paling cepat dan waktu tumbuh miselium jamur sampai memenuhi seluruh permukaan media dalam botol kultur mencapai 30 hari.

\section{UCAPAN TERIMAKASIH}

Terima kasih kepada Direktorat Riset dan Pengabdian Masyarakat, Direktorat Jenderal Penguatan Riset dan Pengembangan Kementerian Riset, Teknologi dan Pendidikan Tinggi, atas dukungannya dalam pelaksanaan kegiatan ini melalui Skema PPUPIK tahun 2021 Universitas Tadulako, sesuai dengan Perjanjian Penugasan Pelaksanaan Program Pengabdian Masyarakat Nomor : 078/SP2H/PPM/DRPM/2021.

\section{DAFTAR PUSTAKA}

Achmad, E.N., Herliyana, I.Z., Siregar, dan O. Permana. 2011. Karakter Morfologi dan genetik Jamur Tiram (Pleurotus ostreatus). Jurnal Hortikultura. 21(3): 225-231.

Hakiki, A., Purnomo, A.S., dan Sukesi. 2013. Pengaruh Tongkol Jagung Sebagai Media Pertumbuhan Terhadap Kualitas Jamur Tiram (Pleurotus ostreatus). Jurnal Sains Dan Seni Pomits. 1(1): 1-4.

Iswahyudi, H., Lukmana, M., dan Yudha, M. 2017. Limbah Serabut Kelapa Sawit sebagai Media Tanam Alternatif bagi Jamur Tiram Putih (Pleurotus Ostreatus). Jurnal Teknologi AgroIndustri. 4(1): 11-19.

Masyitah, S., dan Umrah, U. 2020. Formulasi Media Pertumbuhan Miselium Jamur Tiram Putih (Pleurotus Ostreatus (Jacq) P. Kumm) dengan Suplementasi Limbah Sabut Kelapa. Biocelebes. 14(1): 37-43.

Mayasari, E., Ayuningsih, B., dan Hidayat, R. 2015. Pengaruh Penambahan Nitrogen dan Sulfur pada Ensilase Jerami Jagung terhadap Kecernaan Bahan Kering dan Bahan Organik pada Sapi Potong (in vitro). Students e-Journal Fakultas Peternakan Universitas Padjajaran. 4(3): 1-11.

Mondal, S.R., Rehana, J., Noman, M.S., and Adhikary, S.K. 2010. Comparative study on growth and yield performance of oyster mushroom (Pleurotus florida) on different substrates. Journal of the Bangladesh Agricultural University. 8(2): 213-220.

Murni, R., Suparjo, A., dan Ginting, B.L. 2008. Buku Ajar Teknologi Pemanfaatan Limbah untuk Pakan. Fakultas Peternakan: Universitas Jambi.

Suharnowo, Lukas, S.B., dan Isnawati. 2012. Perumbuhan Miselium dan 
Produksi Tubuh Buah Jamur Tiram Putih (Pleurotus ostreatus) dengan Memanfaatkan Kulit Ari Biji Kedelai sebagai Campuran pada Media Tanam. LenteraBio. 1(3): 125-130.

Sunarmi, Y.I., dan Saparinto, C. 2010. Usaha 6 Jenis Jamur Skala Rumah Tangga. Penebar Swadaya Grup: Jakarta.

Suparti, dan Karimawati, N. 2017. Pertumbuhan Bibit F0 Jamur Tiram (Pleurotus ostreatus) dan Jamur Merang (Volvariella volvacea) Pada Media Umbi Talas Pada Konsentrasi yang Berbeda. Jurnal Bioeksperimen. 3(1): 64-72.

Suparti, S., dan Marfuah, L. 2015. Produktivitas Jamur Tiram Putih (Pleurotus ostreatus) pada Media Limbah Sekam Padi dan Daun Pisang
Kering sebagai Media Alternatif. Jurnal Bioeksperimen. 1(2): 37-44.

Suryani, T., dan Carolina, H. 2017. Pertumbuhan dan hasil Jamur Tiram putih pada beberapa bahan media pembibitan. Jurnal Bioeksperimen. 3 (1): 73-86.

Sutarja. 2010. Produksi Jamur Tiram (Pleurotus ostreatus) Pada Media Campuran Serbuk Gergaji dan Berbagai Komposisi Tepung Jagung dan Bekatul. Tesis. Universitas Sebelas Maret: Surakarta.

Wardiah, W., Linda, L., dan Rahmatan, H. 2014. Potensi Limbah Air Cucian Beras sebagai Pupuk Organik Cair Pada Pertumbuhan Pakchoy (Brassica rapa L.). Jurnal Biologi Edukasi. 6(1): 34-38. 